\title{
Coral Bleaching on Lembongan Island, Nusa Penida, Bali
}

\author{
I Nyoman Dodik Prasetia \\ Jurusan Budidaya Kelautan \\ Universitas Pendidikan Ganesha \\ Singaraja, Indonesia \\ indprasetia@gmail.com
}

\author{
Sutrisno Anggoro ${ }^{1}$, Supriharyono ${ }^{2}$, Lachmuddin S. ${ }^{3}$ \\ ${ }^{1,2,3}$ Program Doktor Manajemen Sumberdaya Pantai \\ Universitas Diponegoro \\ Semarang, Indonesia \\ sutrisno.anggoro@yahoo.co.id ${ }^{1}$, pries1950@gmail.com², \\ lachmuddin.undip@gmail.com ${ }^{3}$
}

\begin{abstract}
The objective of this study was to determine the extent of coral cover that experienced coral bleaching and its impact on coral reef ecosystem. The study was conducted from 2015 to 2016, using manta tow survey method and line intercept transect. Research showed that life coral covering equal to 63 91\%. Coral bleaching occurs $27.51 \%$ at depths of 3 meters and $17.72 \%$ at a depth of 10 meters in June 2016. Coral bleaching consisted of branching coral and massive corals. Reef recovery occurred in November 2016.
\end{abstract}

Keywords-Coral bleaching, Lembongan Island, Coral reef ecosytem

\section{INTRODUCTION}

Since 2014, severe mass coral bleaching has been occurring in most tropical regions across the world in the longest mass bleaching event ever recorded. This global event was triggered by record-breaking sea surface temperatures caused by climate change and amplified by a strong El Nino (Great Barrier Reef Marine Park Authority, 2016). Coral bleaching, due to ocean warming associated with climate change, is one of the most pressing threats to coral reefs worldwide. Mass bleaching events occur during extended periods of elevated sea surface temperatures and have the potential to be widespread, resulting in significant loss of coral (Great Barrier Reef Marine Park Authority, 2016).

Climate change, and its associated impacts, poses the greatest threat to the long-term sustainability of coral reefs worldwide, primarily via mass coral bleaching events. Rapid increases in atmospheric carbon dioxide are consequently warming ocean temperatures beyond thresholds in which corals can thrive (Hughes, et al, 2003; Hoegh-Guldberg, et al 2009). Severe bleaching can cause substantial loss of coral. As corals form the foundation of the reef (Loya et al, 2001; Marshall et al, 2000; Baird and Marshall, 2002), and provide essential habitat to reef fish and invertebrates (Pratchett et al, 2008; Stella et al, 2011), the loss of coral can cause reductions in the populations of other reef inhabitants (Graham, et al, 2007)

When corals become stressed, they lose the zooxanthellae, reveal the white skeleton of the coral, which is known as "bleaching". Bleaching can occur when corals are subject to sea surface temperatures only 1 to $2^{\circ} \mathrm{C}$ above long-term average maximum temperatures (De'ath et al. 2012; Hoegh-
Guldberg et al. 2014). If the thermal stress is mild or shortlived, the corals may survive. If the stress is over an extended period of time, the corals can die or partially die (Putnam and Edwards 2011; Sammarco and Strychar 2013; NOAA 2015b). Thus, lower level bleaching events can also lead to a loss of corals over time (De'ath et al. 2012).

Corals that survive from bleaching may have slower growth and decreased reproduction, and be more susceptible to disease. Coral reefs can take many years to recover after a major bleaching event (GBRMPA 2016c).

In Indonesia, it is reported that coral bleaching affects about two-thirds of coral reefs throughout 2016. The combination of El Nino and global warming are the main causes, in addition to anthropogenic factors damaged the area of water. Most coral bleaching areas are Nusa Tenggara, Bali, and southern Java. Western Sumatra, such as Mentawai, Nias, Central Tapanuli, Sulawesi and Kalimantan are also the area of bleaching based on the results of research conducted by $\mathrm{M}$ Abrar, a coral reef researcher at the Indonesian Institute of Oceanographic Research Center (LIPI) (Kompas, 21 January 2017).

As one of area of coral bleaching, Lembongan Island has a distribution of coral reefs with a reef edge formation with an estimated area of 250 ha (Prasetia, 2006). The reef edge formation contributes to coastal protection from abrasion threats by absorbing wave energy and contributing exciting recreational and tourism services. The coral reef formations that is directly adjacent to human activities result in this formation highly susceptible to degradation. Most coastal damage has been caused by anthropogenic action (Lopes, et al, 2014).

The study of live coral cover in 2003 and 2004 by the Livestock, Fisheries and Marine Service of Klungkung Regency, using Line Intercept Transect (English, et al, 1994), states that the Lembongan Island coral cover is in the range of 21.2-56.5\% In 2003, and in 2004 the value of live coral cover in Lembongan Island waters showed an average closing value of $68.45 \%$ at depth of 3 meters and $48.82 \%$ at a depth of 10 meters.

The coral reef ecosystem of Lembongan Island has a very important value in supporting the joints of community life either directly or indirectly. Utilization of coral reef ecosystem to support community life consists of: 1) fishing activities; 2) 
aquaculture activities; 3) Transportation activities; And 4) tourism activities. This whole activity is based on the social and cultural values of the Lembongan Island community that still adhere to traditional values.

Along with the passage of time, the development of rampant happening in Lembongan Island did not displace the main essence of the existence of coral reefs. Capture fishery activities, seaweed cultivation, tourism, marine transportation, social, and economic communities suppress coral reef ecosystems from all directions. Community activities forget the existence of corals as a resource that is very vulnerable to destruction, and if it happens then collapsed all the joints of life on Lembongan Island.

The objective of this study was to determine the extent of coral cover that experienced coral bleaching and its impact on coral reef ecosystem. The research also aimed to study marine biology in the marine aquaculture, Ganesha University of Education

\section{METHODS}

\section{A. Place and time}

The research was conducted in coastal of Lembongan Island, Nusa Penida, Klungkung, Bali. Lembongan Island is geographically located between 8039 '47.3 "LS - 80 41' 47.7" LS and 115025 '36.6 "BT - 1150 28' 21.3" BT, is a small island located approximately 8 Miles south of the mainland of Bali Island or approximately 16 nautical miles east of Benoa Harbor, Bali.

The location of Lembongan Island has the following limits: North : Badung Strait

East : Toyapakeh Strait

South : Indian Ocean and Ceningan Strait

West : Badung Strait

The study was conducted from May 2015 to December 2016 by conducting preliminary survey, secondary data collection, socialization of research plan to stakeholders who will be the target of survey, primary data collection, and data analysis

\section{B. Research methods}

Research on coral cover and coral abundance was conducted on May and November 2015. The research was started with observation of general condition of coral reef ecosystem in this area by using Manta Tow Survey method. This method is a method of observation / monitoring of a large coral reef community on a large scale in a short time (English, et al, 1994).

Manta Tow Survey method was conducted along the coast with a 2 minute interval recorded on the percentage of coral cover coral cover from closure of live, dead and soft corals (English et al, 1994). Data from the Manta Tow Survey method were analyzed and used as a basis for making a map of the condition of coral reefs in general. This map was served as the basis for determining coral reef observation stations by
Line Intercept Transect method, coral recruitment and coral growth.

Line Intercept Transect method was implemented in June 2015 and November 2015, to see the initial conditions of coral cover and the end of the study. This research was conducted on 4 research stations representing sampling point of the research as shown in Table 1 .

TABLE 1. DESCRIPTION OF RESEARCH StATION

\begin{tabular}{cll}
\hline Station & \multicolumn{1}{c}{ Location } & \multicolumn{1}{c}{ Description } \\
\hline 1 & Pura Sakenan & - Coral reefs \\
& (North of Lembongan & - Seaweed cultivation \\
& Island) & - Tourism activities \\
\hline 2 & Mangrove & - Mangrove \\
& (East of Lembongan & - Coral reefs \\
& Island) & - Tourism activities \\
& & - Seaweed cultivation \\
\hline 3 & Selat Ceningan & - Mangrove \\
& (South of Lembongan & - Coral reefs \\
& Island) & - Seaweed cultivation \\
\hline 4 & Tanjung Sanghyang & - Coral reefs \\
& (West of Lembongan & - Ship activities \\
& Island) & - Tourism activities \\
\hline
\end{tabular}

The study aimed to examine benthic communities based on lifeform characteristics, especially morphology of the coral reef community, so it can be known the diversity of coral species in the area. Line Intercept Transect observations were performed with SCUBA diving at depths of $3 \mathrm{~m}$ and $10 \mathrm{~m}$ (English et al, 1994).

Measurements were made at these two depths with the assumption that these two depths were considered to represent coral conditions as corals normally grow well and high coral diversity is also obtained at these depths.

Research with Line Intercept Transect was conducted to collect data: 1) Closure of coral species on the basis of lifeform; 2) Closure of substrate types on observed coral reefs; 3) Observation of coral reef indicator organisms; 4) coral cover with coral bleaching (English et al, 1994).

\section{Data Analysis}

Analysis of coral cover using Line Intercept Transect method was done by using English, et al (1994). High live coral cover results indicated that the presence of coral reefs in the area in healthy condition was supported by the high index of diversity in the area.

The condition of coral reefs was assessed by following criteria of coral reef damage standard presented by Kementrian Lingkungan Hidup Indonesia (Minister of Environment) No: Kep-04 / MENLH / 02/2001, as in Table 2

TABel 2. Criteria Of CoRAl ReEF Damage Standard

\begin{tabular}{cll}
\hline \multirow{2}{*}{ Poor } & Poor & $0-24,9 \%$ \\
\cline { 2 - 3 } & Fair & $25 \%-49,9 \%$ \\
\hline \multirow{2}{*}{ Good } & Good & $50 \%-74,9 \%$ \\
\cline { 2 - 3 } & Excellent & $75 \%-100 \%$ \\
\hline \multirow{2}{*}{ Source: Kep $04 /$} &
\end{tabular}

Source: Kep-04/MENLH/02/2001 


\section{RESUlTS AND DisCUSSION}

\section{A. Lembongan Island Coastal Condition}

In general, the topography of Nusa Lembongan Island is a flat land with a slope of $0-3 \%$ in the north and a slope of 3 $8 \%$ in the south. Jungutbatu Village has a height of land ranging from 0 to 62 meters above sea level and Lembongan village ranges from 0 - 64 meters above sea level.

The total length of the Lembongan Island coastline is 16.3 $\mathrm{km}$, divided into $9.1 \mathrm{~km}$ in Junggutbatu Village and $7.2 \mathrm{~km}$ in Lembongan Village. Coastal typology consists of sandy beaches along the $4.7 \mathrm{~km}, 5.3 \mathrm{~km}$ bermangrove beach, and 6.4 $\mathrm{km}$ of shore.

White sand beaches are generally spread in the Village Junggutbatu while in Lembongan Village there is only $0.7 \mathrm{~km}$. Lembongan Island beach has a mangrove overgrown beach area of 202 ha. This mangrove forest belongs to a protected forest Registrasi Tanah Kehutanan (RTK) or Land Registration Forestry 22.

The tidal pattern in Nusa Lembongan Island has the same pattern with the clusters of the islands of Nusa Penida and Ceningan is semi-diurnal where on a day there are two tides and twice receded, but one of the highs and lows exceeds the tides and the other. Reach outreach in this area is relatively long from the coastline of Nusa Lembongan Island.

The current pattern in Nusa Lembongan Island is influenced by the macro current pattern of mass water movement in the waters of the Bali Strait, Lombok Strait and Ocean of Indonesia. In east seasons the water mass to the west of Nusa Lembongan Island is deflected to the north, whereas in the north of the island the water mass is deflected to the northeast. In the western seasons the water masses in the northern waters of the island partly move eastward and partially deflected into the Strait of Toyapakeh. The current pattern of micro currents in the shallow waters of Nusa Lembongan Island varies greatly and is strongly influenced by tidal movement.

\section{B. Coral Reef on Lembongan Island}

\section{Coral covering of the year 2015}

The manta tow survey results were known in the North of Nusa Lembongan Island to have live coral cover category between 3 - 5, which means that the coral cover is $41 \%$ $100 \%$. The area which is between Tanjung Ental, Sakenan Temple to Tanjung Pemaroan is an area that is often used as a tourist area because of its reef beauty. The strong currents in this area resulted in the closing of live corals of branching, massive, and soft coral species dominating this area. Seaweed cultivation activities were conducted in the area on the edge of the island to a depth of 3 meters.

The coral reefs in the South Island Nusa Lembongan Island had a category between 1 - 3 with a percentage of $0 \%$ $40 \%$. Seaweed cultivation developed in Ceningan Strait is a factor that depresses the existence of coral reef ecosystem in this area.

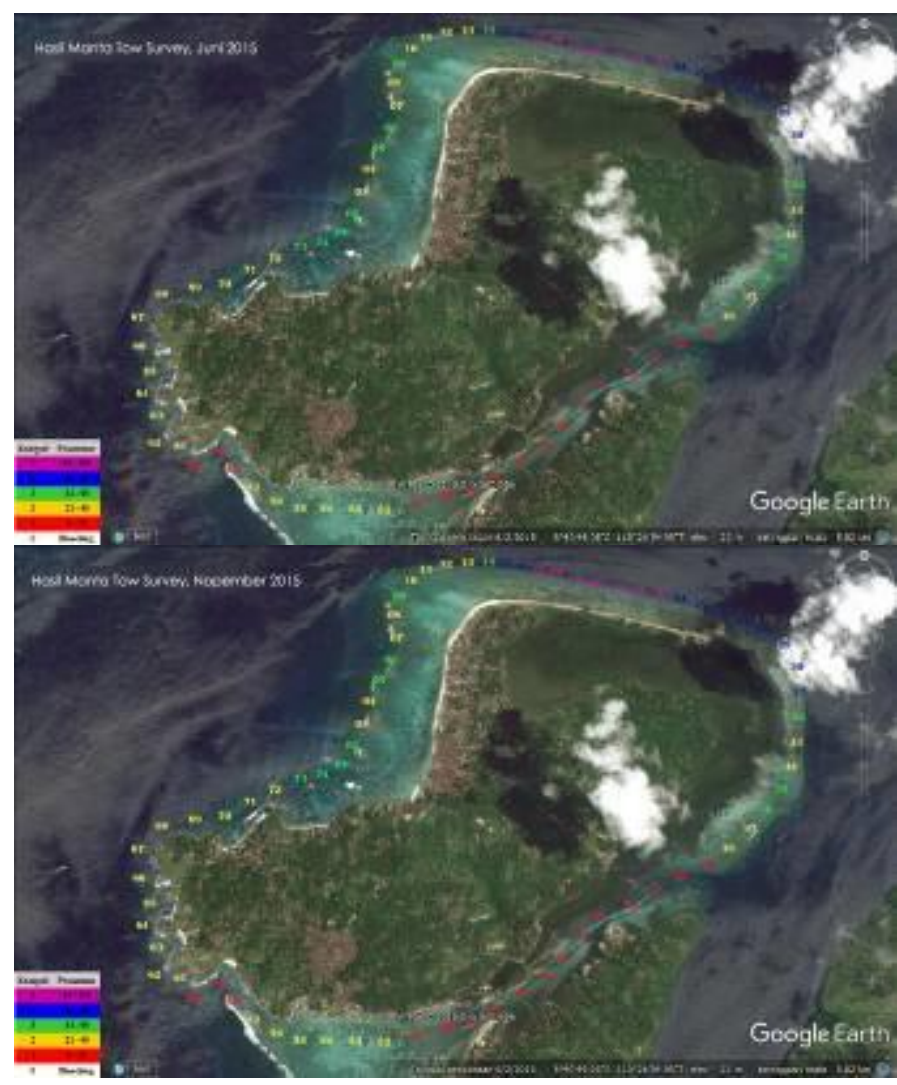

Fig.1. Manta Tow Survey June And November 2015

The western part of Lembongan Island had a live coral cover percentage of $21 \%$ to $80 \%$ with categories 2 to 4 . This area is an area that is used as a tourism area, both marine tourism and accommodation facilities. In addition to the use of seaweed cultivation tourism was also done in this area.

The eastern part of Lembongan Island had a living coral closure condition with categories ranging from 2 to 4 , with a percentage between $21-80 \%$. This area is a mangrove forest owned Lembongan Island. The existence of mangroves in this area gives a double meaning to the coral reefs; on one side of the mangrove protect it from input from the mainland and on the other side at the ebb and subsidence of the mangrove move towards the coral reefs. Activities undertaken in this area was the cultivation of seaweed in the area in front of the mangrove forest. 


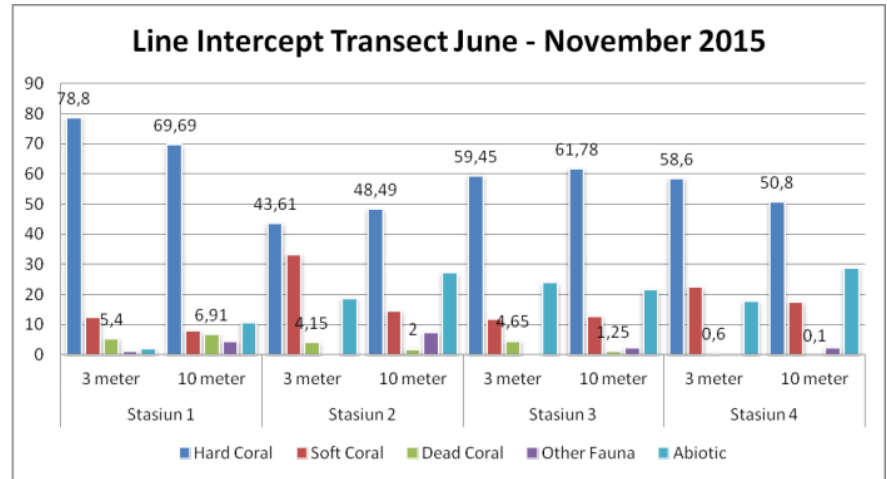

Fig.2. Line Intercept Transect June - November 2015

In general, the condition of live coral cover on Lembongan Island had a percentage of closure between $43.61 \%$ to $78.8 \%$ at a depth of 3 meters, while at a depth of 10 meters ranges from $48.49 \%$ to $69.69 \%$.

The high coverage of live corals indicated environmental conditions that supported the sustainability of coral reefs in the region. The harshness of the currents that carried the substrate as coral food also served to minimize human activity in the coral reef area of Nusa Lembongan Island.

The coral reef structure on Lembongan Island had Acropora, Non Acropora, and soft coral formations. Acropora groups are generally branching, tabulate and submassive, Non Acropora group with lifeform: branching, massive, encrusting, submassive, foliose and mushroom

The presence of soft corals dominated the live coral cover in the structure of the Lembongan reef community, its shape or its soft life form support the ability of soft corals to survive the conditions of strongly flowing waters. Soft corals in the waters of Lembongan Island are dominated by Lobophyton sp, Sarcophyton sp, and Sinularia sp. Strong currents and water movements in this region caused corals to adapt to soft but strong shapes in essence by sticking to their substrate.

\section{Coral covering of the year 2016}

The coral cover conditions of Lembongan Island in 2016 and 2015 had relatively similar living coral cover conditions. However, in June 2016 there was a phenomenon of coral bleaching in the North and West of Lembongan Island

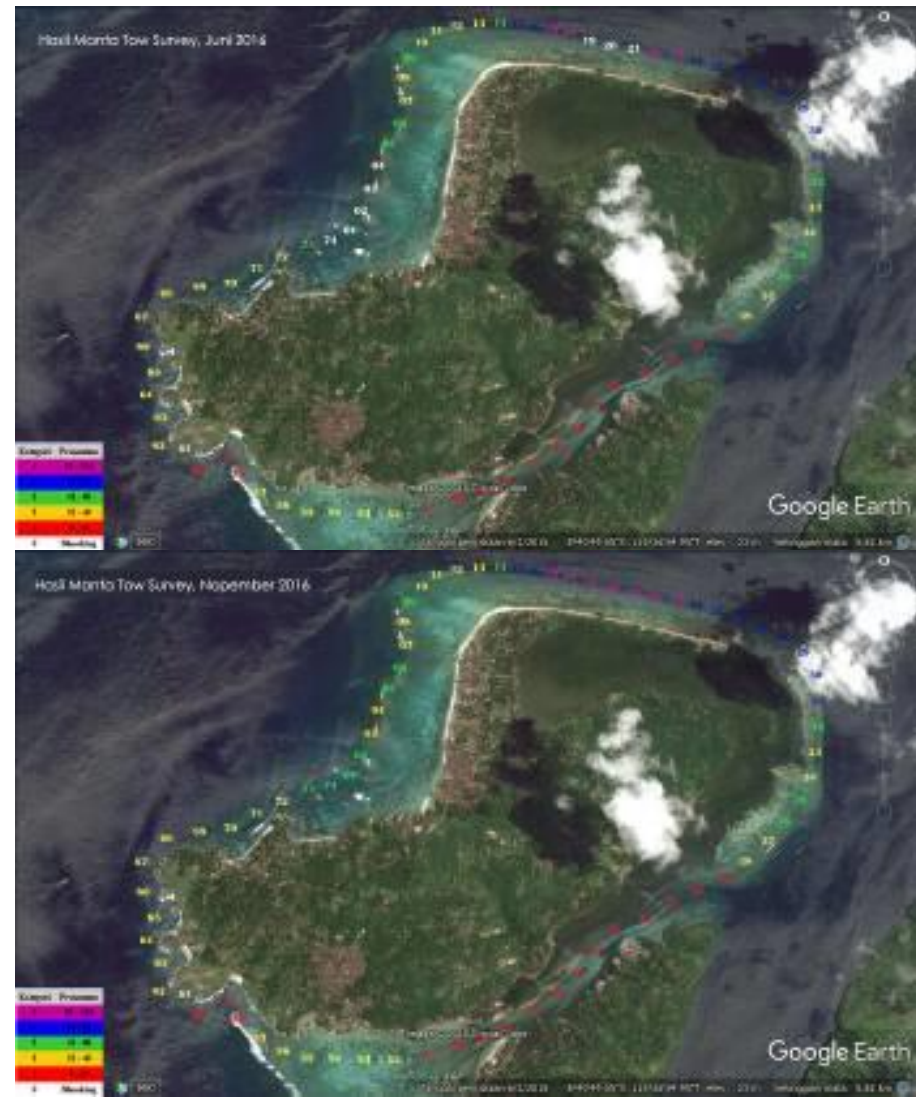

Fig.3. Manta Tow Survey June and November 2016

Coral bleaching occurs at Station 2 on the 3 meter depth where $27.51 \%$ Acropora branching was bleaching. Station 4 at 3 meters depth occurred coral bleaching at: 17,72\% Acropora branching, 8.3 branching and $6.8 \%$ Coral massive

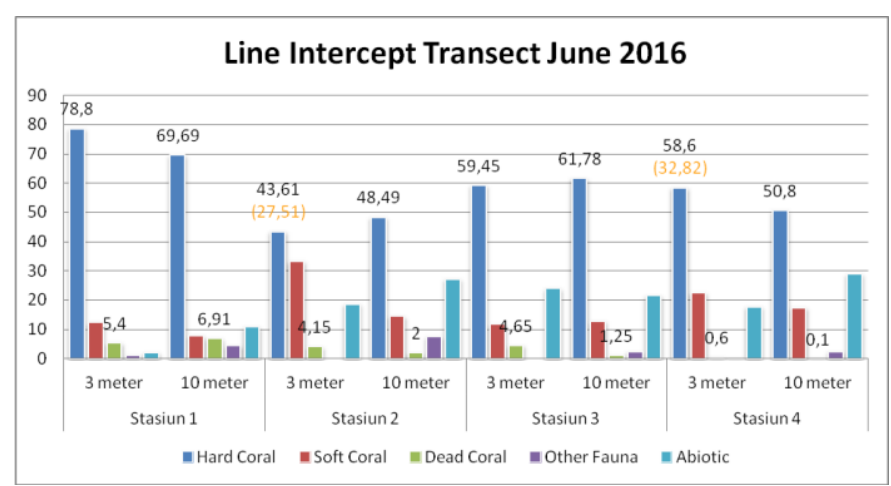

Fig.4. Line Intercept Transect June 2016

Coral bleaching occurring at a depth of 3 meters caused some clusters of massive corals to experience bleaching. Coral bleaching as seen in Figures 5 and 6 


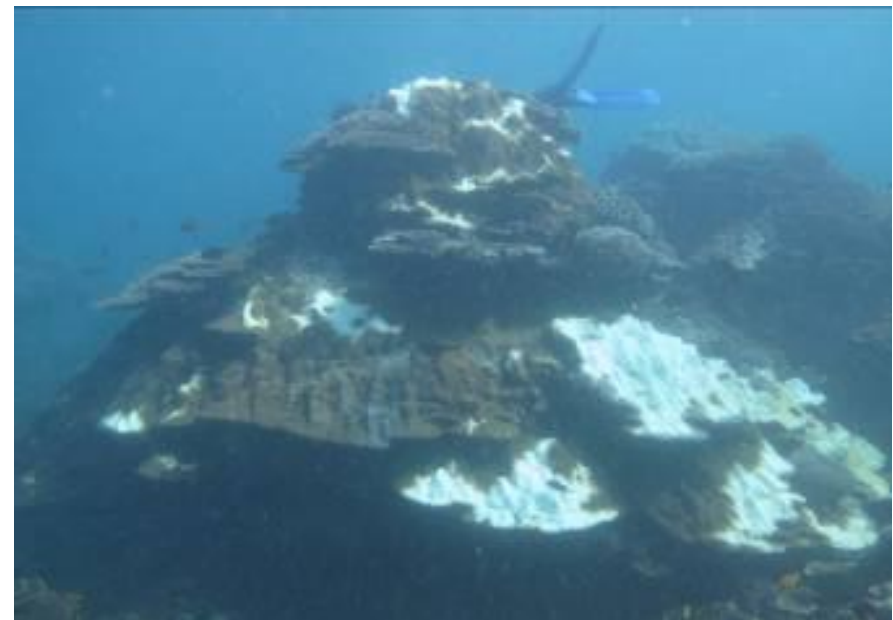

Fig.5. Bleaching Coral on Lembongan Island

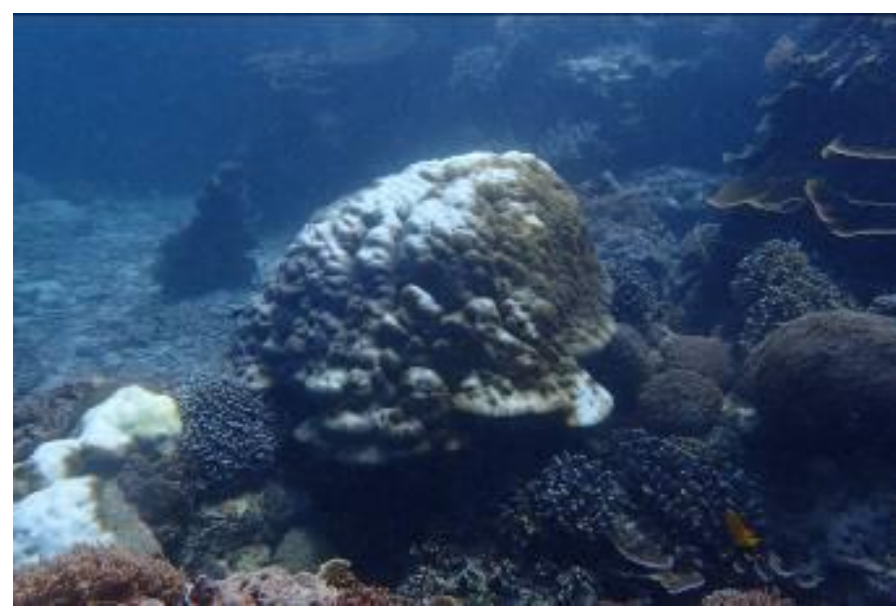

Fig.6. Bleaching Coral on Lembongan Island

Observations in November 2016 showed a recovery in coral bleaching in June 2016

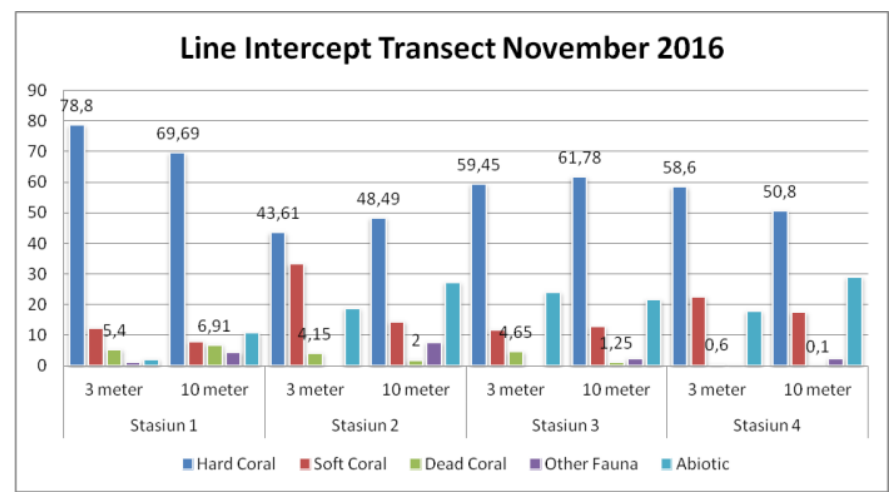

Fig.7. Line Intercept Transect November 2016

The result of line intercept transect showed closure between $43,61 \%$ to $78,8 \%$ at depth of 3 meter, while in depth 10 meter ranged from $48,49 \%$ until $69,69 \%$.

\section{Coral Bleaching Factors in 2016}

Human activities, primarily the emission of greenhouse gases from the combustion of fossil fuels (coal, oil and gas), are driving climate change. The changing climate is putting the Earth's biodiversity and ecosystems at very high risk of serious impacts this century (Gattuso et al. 2015)

Coral reef growth is strongly influenced by such limiting factors:

\section{Temperature (Controlling Factor)}

Record global ocean temperatures associated with a severe El Niño event, marked by up to $3^{\circ} \mathrm{C}$ warmer-than-average sea surface temperatures in the central and eastern equatorial Pacific Ocean over the past year or so, on top of the long-term warming trend, prompted NOAA to declare a global bleaching event in October 2015, because the phenomenon was evident in all three ocean basins, the Indian, Pacific, and Atlantic/ Caribbean (NOAA 2015a; Hoegh-Guldberg 2016). A global event such as this has only been declared twice before - in 1998 and 2010 (NOAA 2015a; Wake 2016).

The most optimal coral reef development if the average annual temperature is $23-25^{\circ} \mathrm{C}$ and close to tropical conditions (Nybakken, 1992., Lalli and Parsons, 1993). But at 25-30 ${ }^{\circ} \mathrm{C}$ temperature temperatures coral growth can still live optimally (Nontji, 1987). Temperature has an important role in limiting the distribution of coral reefs, since hermatypic corals as the main constituent component have optimal growth at an average temperature above 200C throughout the year (Barner and Hughes, 1990). Therefore, coral reefs are not found in temperate climates especially in cold areas.

Bleaching is not the only threat to coral reef habitats and its impacts cannot be viewed in isolation from the legacy impacts of past practices and current pressures. These pressures include severe tropical cyclones, coral predation by the crown-of-thorns starfish, poor water quality and direct use

\section{Ligh (Limiting Factor)}

According to Nybakken (1992), coral reefs have a compensatory point of reduced light intensity up to $15-20 \%$ of the surface at a depth of $25 \mathrm{~m}$ or less, in order for optimal development in the waters. Light together with zooxanthellae is an environmental factor that controls coral vertical distribution and coral reef calcification rates by individuals from each colony (Supriharyono, 2000).

Light is needed for photosynthesis of symbiotic algae ie zooxanthellae whose production is then donated to coral animals that become its host. Without sufficient light, the rate of photosynthesis of zooxanthellae is reduced and at the same time the coral reefs to deposit calcium carbonate and reef form will be reduced (Notji, 1987, Nybakken, 1992).

\section{Sedimentation and Turbidity (Controlling Factor)}

According to Supriharyono (2007), there is a sediment known as carbonate sediment, which is sediment derived from coral erosion. Physically or biologically called bioerosion. 
Bioeorsi is usually done by marine animals, such as sea urchins, fish, starfish and so on.

The existence of these sediments, both terrigeneous sediments and carbonate sediments, causes the waters around the coral reef to become turbid, especially after major rain or storms, and this can affect the life of the reef.

Sedimentation directly and indirectly affects coral growth because of the amount of energy released to dispel this sediment from the polyp surface (Supriharyono, 2000). Increased sediments will kill corals and additional nutrients can cause corals overgrown with algae that are competing corals in life (Anonymous, 2001). This is because excessive sediments can kill corals, because the oxygen dissolved in water cannot diffuse into the coral polyps (Dahuri et al., 1996)

Sediments in sea water columns can greatly affect coral growth, or even cause coral mortality. High nutrient content of river flow can stimulate the growth of toxic algae. This leads to the growth of other algae that not only utilize solar energy but also inhibits coral larvae colonization by overgrowing the substrate which is the site for coral larvae (Burket et al. 2002)

Turbidity of water can reduce the intensity of incoming light and can cause disturbed until the death of coral reefs (Supriharyono, 2000). If the water is cloudy, the corals can only grow at a depth of 2 meters. Whereas in clear blue waters around the oceanic islands, corals can grow to depths of more than 80 meters.

\section{Pollutants (Toxic Factor)}

Oil spill causes reduced coral species colony, reproduction rate, number of ovaries per polyp, number of planula produced per individual, and decreasing number of successful planula attached to the substrate (Supriharyono, 2000). This is because the oil layer can reduce the intensity of sunlight that coral needs in the process of photosynthesis.

\section{Protect Coral Reefs}

The fact that bleaching is having greater and greater impacts example bleaching and mortality over time is strong evidence that corals are not able to acclimatize adequately to the rate of increase in ocean temperature.

These ecosystems protect coastlines from storms and erosion and provide habitat, spawning and nursery grounds for $25 \%$ of marine species, including many economically important fish. Coral ecosystems also provide jobs and income to local communities from fishing, recreation, and tourism, supporting livelihoods of 500 million people globally. Loss of coral reefs potentially puts an astounding $\$ 1$ trillion at risk globally (Hoegh-Guldberg et al. 2015).

The future of coral reefs depends on how much and how fast we reduce greenhouse gas emissions now, and in the coming years and decades (Hoegh-Guldberg 1999; HoeghGuldberg et al. 2007; De'ath et al. 2012). Global emissions must be trending downwards by 2020 at the latest.
Renewable energy investment and implementation must therefore increase rapidly and most of the known fossil fuel reserves must remain in the ground (McGlade and Ekins 2015).

One way to protect corals is to learn the coral bleaching phenomenon. The more data will be more and more references that can be used for anticipation. Written data and facts can be used as a reference in learning on campus.

This research can be used as teaching material in marine biology. To strengthen the understanding of the factors that affect coral bleaching. It is also important for the management of sustainable coral reef areas. Coral bleaching can be a sign of environmental degradation that disrupts coral growth.

\section{CONCLUSION}

Based on the results, it can be concluded that; (1) live coral cover on Lembongan Island has percentage between 43,61\% to $78,8 \%$ at depth of 3 meter, while in depth 10 meter ranged from $48,49 \%$ until $69,69 \%$, (2) coral bleaching occurred at Station 2 on the 3 meter deep where $27.51 \%$ Acropora branching. Station 4 at 3 meter depth occurred coral bleaching at: $17,72 \%$ Acropora branching, $8.3 \%$ branching rock, and $6.8 \%$ Coral massive, (3) coral bleaching on Lembongan Island is caused by Climate change and its associated impacts and (4) observations in November 2016 show a recovery in coral bleaching in June 2016.

\section{ACKNOWLEDGMENT}

This research is part of a dissertation entitled Model and Strategy of Coral Reef Ecosystem Management in Lembongan Island Bali with Co-Management Approach based on Carryng Capacity by I Nyoman Dodik Prasetia. Program Doctor of Coastal Resource Management, Faculty of Fisheries and Marine Sciences, University of Diponegoro, Semarang. With Promoter: Prof. Dr. Ir. Supriharyono, MS., Prof. Dr. Ir. Sutrisno Anggoro, MS, and Prof. Dr. Ir. Lachmuddin Sya'rani.

\section{REFERENCES}

[1] Baird, A.H. and Marshall, P.A. 2002, Mortality, growth and reproduction in scleractinian corals following bleaching on the Great Barrier Reef, Marine Ecology Progress Series 237: 133-141.

[2] Barnes, R. S. K. and Hughes. 1990. An Introduction to Marine Ecology. Blacwell Scientific Publisher. London

[3] Burke L., Selig E., Spalding M., 2002 Terumbu Karang Yang Terancam di Asia Tenggara (Ringkasan untuk Indonesia), World Resources Institute, Amerika Serikat

[4] Dahuri, R., Jacub Rais., Sapta Putra Ginting., dan M.J. Sitepu. 1996. Pengelolaan Sumber Daya Wilayah Pesisir dan Lautan Secara Terpadu. PT. Pradnya Paramita. Jakarta

[5] De'ath G, Fabricius KE, Sweatman H and Puotinen M (2012) The 27year decline of coral cover on the Great Barrier Reef and its causes. Proceedings of the National Academy of Sciences, 109:17995-17999. 
[6] English, S.C. Wilkinson, and V. Baker, 1994. Survey Manual for Tropical Marine Resources, Australia Institute of Marine Science. Townsville

[7] Gattuso JP, Magnan A and Billé A (2015) Contrasting futures for ocean and society from different anthropogenic $\mathrm{CO}_{2}$ emissions scenarios. Science, 349:45.

[8] Graham, N.A.J., Wilson, S.K., Jennings, S., Polunin, N.V.C., Robinson, J.A.N., Bijoux, J.P. and Daw, T.M. 2007, Lag effects in the impacts of mass coral bleaching on coral reef fish, fisheries, and ecosystems, Conservation Biology 21(5): 1291-1300.

[9] Great Barrier Reef Marine Park Authority 2016, Interim report: 2016 coral bleaching event on the Great Barrier Reef, GBRMPA, Townsville

[10] Hughes, T.P., Baird, A.H., Bellwood, D.R., Card, M., Connolly, S.R., Folke, C., Gosberg, R., Hoegh-Guldberg, O., Jackson, J.B.C., Kleypas, J.A., Lough, J.M., Marshall, P.A., Nyström, M., Palumbi, S.R., Pandolfi, J.M., Rosen, B. and Roughgarden, J. 2003, Climate change, human impacts, and the resilience of coral reefs, Science 301: 929-933

[11] Hoegh-Guldberg O (1999) Coral bleaching, climate change and the future of the world's coral reefs. Marine Freshwater Research, 50:839866.

[12] Hoegh-Guldberg, O., Hughes, T., Anthony, K., Caldeira, K., Hatziolos, M. and Kleypas, J. 2009, Coral reefs and rapid climate change: impacts, risks and implications for tropical societies, in Climate change: global risks, challenges and decisions. IOP conference series: earth and environmental science, eds. Anonymous, IOP Publishing, pp. 1-2

[13] Hoegh-Guldberg O (2016) It's not 'doom and gloom' to point out what's really happening to coral reefs. The Conversation, 4 March 2016. Accessed at https:// theconversation.com/its-not-doom-and-gloom-topoint-out-whats-really-happening-to-coral-reefs-55695.

[14] Hoegh-Guldberg O, Mumby P, Hooten A, Steneck R, Greenfield P, Gomez E, Harvell C, Sale P, Edwards A and Caldeira K (2007) Coral reefs under rapid climate change and ocean acidification. Science 318:1737-1742.

[15] Lalli, C. M and F. R. Parsons, 1993. Biological Oceanography An Introduction. Pergamon Press. Oxford

[16] Lopes, P. F. M., S. Pacheco., M. Clauzet., R. A. M. Silvano., dan A. Begossi. 2014. Fisheries, Tourism, and Marine Protected Areas: Conflicting or Synergistic Interactions. Ecosystem Services

[17] Loya, Y., Sakai, K., Yamazato, K., Nakano, Y., Sambali, H. and van Woesik, R. 2001, Coral bleaching: the winners and the losers, Ecology Letters 4(2): 122-131.

[18] McGlade C and Ekins P (2015) The geographical distribution of fossil fuels unused when limiting global warming to $2^{\circ} \mathrm{C}$. Nature, 517(7533), 187-190.

[19] Marshall, P.A. and Baird, A.H. 2000, Bleaching of corals on the Great Barrier Reef: differential susceptibilities among taxa, Coral Reefs 19(2): 155-163.

[20] NOAA (National Oceanic and Atmospheric Administration) (2015a) NOAA declares third ever global coral bleaching event: Bleaching intensifies in Hawaii, high ocean temperatures threaten Caribbean corals. October 8, 2015. Accessed at http://www.noaanews.noaa.gov/ stories2015/100815-noaa-declares-third-ever-global-coral-bleachingevent.html.

[21] Notji, A. 1987. Laut Nusantara. Penerbit Djambatan. Jakarta

[22] Nybakken, J. W. 1992. Biologi Laut, Suatu Pendekatan Ekologis. Alih Bahasa : H. M. Eidman, Koesoebiono, D. G. Bengen, M. Hutomo dan S. Sukardjo. PT. Gramedia. Jakarta

[23] Pratchett, M.S., Munday, P.L., Wilson, S.K., Graham, N.A.J., Cinner, J.E., Bellwood, D.R., Jones, G.P., Polunin, N.V.C. and McClanahan, T.R. 2008, Effects of climate-induced coral bleaching on coral-reef fishes: ecological and economic consequences, Oceanography and Marine Biology: An Annual Review 46: 251-296

[24] Prasetia, I. N. D. 2006. Study of Coral Recruitment in Nusa Lembongan Island, Nusa Penida, Klungkung, Bali. Post Graduate Program Udayana University Denpasar

[25] Stella, J.S., Pratchett, M.S., Hutchings, P.A. and Jones, G.P. 2011, Coral-associated invertebrates: diversity, ecological important and vulnerability to disturbance, Oceaongraphy and Marine Biology: An Annual Review 49: 43-104

[26] Supriharyono. 2000. Pengelolaan Ekosistem Terumbu Karang. Penerbit Djambatan. Jakarta

[27] Supriharyono. 2007. Konservasi Ekosistem Sumberdaya Hayati di Wilayah Pesisir dan Laut Tropis. Pustaka Pelajar. Yogyakarta

[28] Wake B (2016) Snapshot: Snow white coral. Nature Climate Change 6 , 439, doi:10.1038/nclimate3009. 